\title{
Teknologi Pengolahan Limbah Industri Tahu Sebagai Upaya Pengembangan Usaha Kecil Menengah (Ukm) Di Kecamatan Gambiran Kabupaten Banyuwangi
}

\author{
Sofi Faiqotul Hikmah, Abd. Rahman, Ilham Nur Kholiq, \\ Zulfi Zumala Dwi Andriani \\ Institut Agama Islam Darussalam (IAIDA) Blokagung Banyuwangi \\ sofiefaiqotul@gmail.com, abdrahman@mail.com, choliq89@gmail.com,
}

zumaladwi@gmail.com

\begin{abstract}
If waste is utilized properly, it will create new production and advance SMEs in Gambiran District so that it can minimize unemployment and increase the amount of income per capita of the community. This study has three objectives, namely: (1) To analyze the technology used in processing tofu industrial waste into nata de soya in Gambiran District, Banyuwangi Regency, (2) To analyze the technology used for processing tofu industrial waste into soy sauce in Gambiran District Banyuwangi, (3) To analyze the amount of production costs and costs of production sales from nata de soya and soy sauce products as an effort to develop Small and Medium Enterprises (UKM) in Gambiran District, Banyuwangi Regency. This research is classified into descriptive research with quantitative and qualitative types of data from the results of the experimental application to examine the act of making nata and soy sauce food products by the Gambiran District community by collecting data through surveys, observations, documentation, interviews and document analysis. In analyzing the document the results of the study will compare the feasibility of the two products obtained from whey to Nata de Soya and Ketchup products. The analysis shows that the technology used in making nata de soya is biotechnology from the bacterium Acetobacter xylinum which has been fermented with sugar, vinegar and micin. While the technology of utilizing tofu industrial waste into soy sauce is one strategy to reduce environmental pollution. Experiments of making soy sauce are carried out by fermentation by methanogen bacteria from soaking solid waste and fermented with salt water bath after the tofu waste is dried until the moisture content reaches $12 \%$. To analyze the production cost of making nata de soya with 3 liters of liquid waste is $T C I=16,500, T C=16,500, T R=25,500, \Pi=9,000, B E P=6$ Liters. While for the analysis of the production cost of making soy sauce is $T C I=$ 33,000, $T C=33,000, T R=75,500, \Pi=42,000, B E P=2.2$ Liter
\end{abstract}

\section{Keywords : Tofu Industry Waste, Nata de Soya, Kecap, UKM}

\section{PENDAHULUAN}

Di Kabupaten Banyuwangi sangat banyak sekali dijumpai pabrik tahu dengan berbagai ukuran jumlah produksinya, bahkan salah satu kecamatan memiliki ratusan industri tahu yang nilai produksinya mencapai miliaran rupiah, yaitu sekitar 3,022 miliar dengan jumlah nilai investasi mencapai 582 juta dengan jumlah tenaga kerja 
Vol.5 / No.1: 36-71, Januari 2019,

ISSN : 2599-3348 (online)

ISSN : 2460-0083 (cetak)

sebanyak 109 orang. Ada lima kecamatan yang disebut sebagai sentra tahu terbesar di Kabupaten Banyuwangi, yaitu Kecamatan Gambiran, Genteng, Srono, Rogojampi dan Pesanggaran. Dari urutan tersebut Kecamatan Gambiran menduduki peringkat pertama Kecamatan yang mempunyai industri tahu terbanyak, yaitu terdapat di Desa Gambiran dengan jumlah 37 produksi, dan di Desa Purwodadi sebanyak 41 industri tahu yang dikelola oleh masyarakat (Dinas Perindustrian Perdagangan dan Pertambangan (Disperindag), 2016, Kabupaten Banyuwangi).

Salah satu dampak negatif yang ditimbulkan dengan adanya industri tahu yaitu limbah dari pembuatan tahu. Limbah selalu menjadi masalah utama dan sulit ditanggulangi. Dalam proses pembuatan tahu, limbah terdiri dari dua bagian yaitu limbah padat dan limbah cair (whey) dari sisa produksi tahu. Limbah padat dari pembuatan tahu biasanya dimanfaatkan menjadi "tempe gembos" dan juga pakan ternak sapi dan bebek. Tempe gembos merupakan limbah padat dari hasil produksi tahu yang biasanya dijual dengan harga murah di pasar yaitu Rp. 500. Selain itu tidak sedikit juga masyarakat yang memanfaatkan limbah padat tahu menjadi krupuk ampas tahu, abon ampas tahu, pembuatan roti ampas tahu dan lain-lain. Limbah padat tahu banyak dimanfaatkan oleh masyarakat sekitar, sehingga sejauh ini tidak ada permasalahan yang ditimbulkan akibat limbah padat industri tahu, karena banyak manfaatnya.

Salah satu sungai yang digunakan untuk pembuangan limbah cair industri tahu. Pemilik industri tahu yang membuang limbah cairnya ke sungai hingga menyebabkan warna air sungai menjadi putih padahal sungai terbut adalah salah satu sungai yang digunakan oleh petani untuk mengairi sawahnya. Sungai yang banjir tidak menjadi masalah ketika pemilik industri tahu membuang limbah cairnya ke sungai, tapi ketika sungai tidak ada airnya mereka yang tetap membuang limbah cairnya menjadi masalah bagi warga sekitar, karena air yang ada di sungai menjadi berbau tidak sedap dan mengganggu warga yang lewat dan yang bertempat tinggal di sekitar sungai. Ini adalah salah satu dampak negatif dari pembuangan limbah cair tahu di sungai ketika air sungai tidak mengalir.

Sedangkan untuk limbah cair dari produksi tahu ini yang masih jarang dimanfaatkan oleh masyarakat sekitar, hal itu menjadi masalah terbesar karena limbah cair tahu (whey) oleh produsen dibuang begitu saja di sungai dan selokan sehingga limbah cair tahu dapat memcemari lingkungan terutama sungai. Selain itu limbah cair tahu yang dibuang di sungai yang tidak mengalir oleh produsen tahu akan menimbulkan bau yang tidak sedap sehingga mengakibatkan pencemaran udara, sungai dan tanah.

Dari hasil interview sementara kepada Kepala Desa Purwodadi Kecamatan Gambiran, industri tahu yang ada di Kecamatan Gambiran Kabupaten Banyuwangi melakukan proses produksi rata-rata sebesar 1 ton lebih kedelai per hari, dan dari proses tersebut akan dihasilkan limbah cair berupa whey sebesar 8500 L/hari. Limbah cair yang dihasilkan industri tahu yang ada di Kecamatan Gambiran cukup besar, jika $8500 \mathrm{~L}$ dari limbah tersebut dimanfaatkan maka akan membantu 
Vol.5 / No.1: 36-71, Januari 2019,

ISSN : 2599-3348 (online)

ISSN : 2460-0083 (cetak)

mengurangi kontribusi pabrik tahu dalam mencemari lingkungan. Permasalahan ini perlu dipikirkan adanya alternatif pemecahan dengan memanfaatkannya menjadi produk nata de soya dan kecap, karena di dalam air limbah tahu masih mengandung bahan-bahan organik seperti protein, lemak dan karbohidrat (Sulik Sutiyani, dkk., 83).

Limbah cair tahu (whey) merupakan sisa dari proses pencucian, perendaman, penggumpalan, dan pencetakan selama pembuatan tahu. Limbah cair tahu banyak mengandung bahan organik dibandingkan bahan organik. Kandungan protein limbah cair tahu mencapai 40-60 \%, karbohidrat 25-50\%, dan lemak $10 \%$. Bahan organik berpengaruh terhadap tingginya fosfor, nitrogen, dan sulfur dalam air (Nurul Nikmah, 2016: 46).

Konsumsi kecap dan nata meningkat dari tahun ketahun, dimana bedasarkan informasi diperoleh dari hasil survei beberapa penjual es campur dan beberapa minuman terhadap kebutuhan nata di Kabupaten Banyuwangi. Sedangkan untuk konsumsi kecap jauh lebih besar daripada konsumsi nata, berdasarkan informasi yang diperoleh dari beberapa toko atau pedagang kelontongan, karena kecap merupakan bumbu yang sering digunakan untuk memasak makanan.

Produk nata de soya dan produk kecap dalam proses produksinya membutuhkan faktor-faktor produksi dan jumlah bahan baku limbah tahu yang sama besar, secara ekonomi akan memberikan keuntungan yang berbeda. Perbedaan keuntungan yang dihasilkan oleh produk nata de soya dan produk kecap diketahui dengan melakukan beberapa analisa ekonomi, produk yang mempunyai skala ekonomi tinggi merupakan alternatif pemecahan terbaik sehingga penelitian ini perlu dilakukan.

Dalam pembuatan nata maupun kecap sudah pasti memerlukan bahan-bahan dan alat untuk proses pembuatannya, sehingga biaya produksi dalam pembuatan kedua produk tersebut harus diperhatikan seiring dengan kebutuhan dan permintaan nata dan kecap karena jika biaya produksi pembuatan kecap atau nata lebih besar dari pada total penjualan dan besarnya manfaat untuk masyarakat Kecamatan Gambiran maka akan merugikan produsen. Untuk pembuatan nata dan kecap di Kecamatan Gambiran Kabupaten Banyuwangi, jika bisa meminimalisir biaya produksi maka dapat dijadikan alternatif untuk membuka peluang baru bagi masyarakat yang masih pengangguran untuk mendirikan usaha baru atau dapat bersaing dengan produsen tahu, sehingga peluang tersebut dapat memajukan Usaha Kecil Mengengah (UKM) yang ada di Kabupaten Banyuwangi dengan adanya inovasi dan teknologi baru tersebut. Kemajuan UKM yang ada di Kabupaten Banyuwangi akan meringankan beban pemerintah daerah dalam hal pengurangan jumlah angka kemiskinan yang ada di Kabupaten Banyuwangi.

UKM merupakan salah satu hal terpenting dalam lajunya perekonomian daerah. UKM membantu pemerintah daerah dalam menciptakan suatu lapangan pekerjaan baru sehingga masyarakat tidak bergantung pada bantuan dari pemerintah daerah. Hal tersebut dikarenakan masyarakat yang masih miskin atau belum punya 
Vol.5 / No.1: 36-71, Januari 2019,

ISSN : 2599-3348 (online)

ISSN : 2460-0083 (cetak)

pekerjaan sudah bisa berinovasi dan berkreasi dengan memanfaatkan potensi yang sering diabaikan oleh masyarakat sehingga bisa menambah jumlah pendapatan dan mengurangi pengangguran. Yaitu potensi limbah industri tahu yang ada di Kecamatan Gambiran Kabupaten Banyuwangi bisa digunakan alternatif untuk peluang berdirinya UKM baru sehingga produksi limbah industri tahu bisa bersaing dengan industri tahu itu sendiri yang akan memajukan perekonomian daerah.

Penelitian ini berencana akan memanfaatkan limbah industri tahu yang ada di Kecamatan Gambiran untuk pembuatan pangan yaitu nata de soya dan kecap yang menurut hasil survey semakin banyak permintaan terhadap kedua produk ini di pasar, dengan memanfaatkan bioeknologi yang berasal dari bakteri, kedua produk tersebut bisa dibuat. Pembuatan pangan dari limbah industri tahu ini akan dibandingkan nilai produksi yaitu total biaya yang dikeluarkan dalam pembuatan kedua produk pangan tersebut, dan nilai jual serta besarnya manfaat yang dihasilkan dari kedua produk pangan ini yaitu Nata de Soya dan Kecap. Rumusan masalah yang dibangun adalah : Bagaimana teknologi pemanfaatan limbah industri tahu menjadi nata de soya di Kecamatan Gambiran Kabupaten Banyuwangi ?, Bagaimana teknologi pemanfaatan limbah industri tahu menjadi kecap di Kecamatan Gambiran Kabupaten Banyuwangi ?, dan Bagaimana besaran biaya produksi nata de soya dan kecap sebagai upaya pengembangan Usaha Kecil Menengah (UKM) di Kecamatan Gambiran Kabupaten Banyuwangi ?.

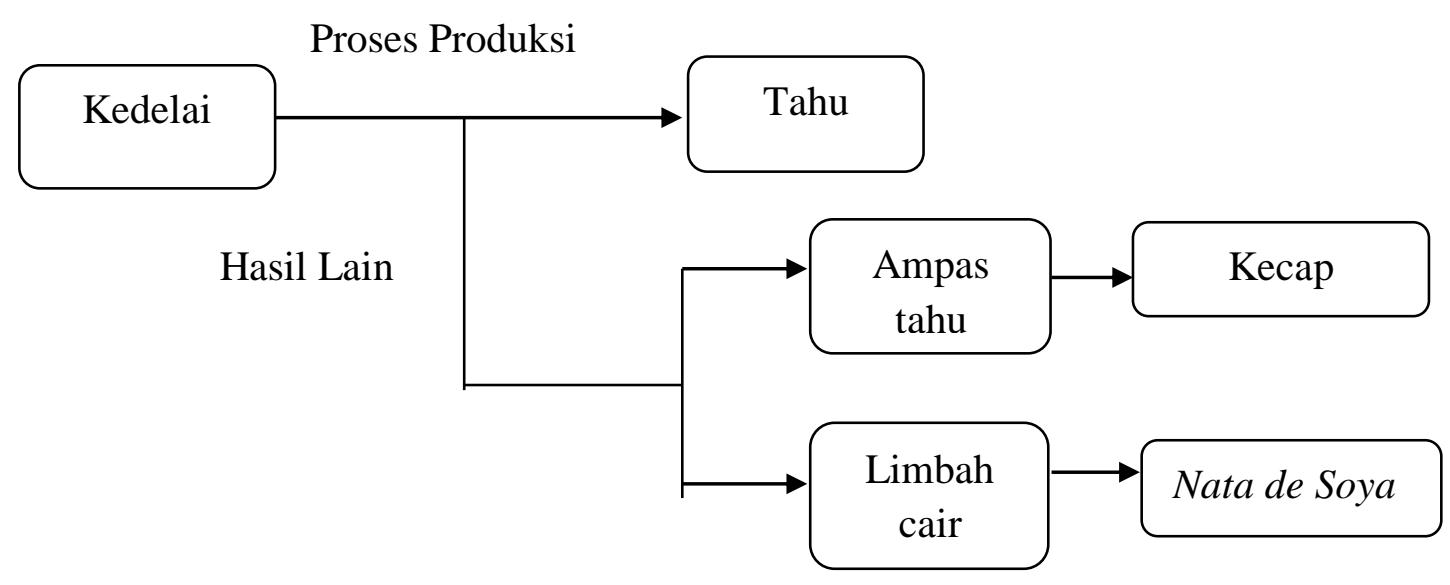

Gambar 1. Rencana Proses dan Hasil Pembuatan Tahu dalam Penelitian

\section{KAJIAN TEORI}

\section{Limbah}

Limbah merupakan buangan atau sisa yang dihasilkan dari suatu proses atau kegiatan dari industri maupun domestik (rumah tangga). Menurut peraturan pemerintah Nomor 101 tahun 2014, limbah adalah sisa suatu usaha atau kegiatan. Ada tiga bentuk limbah yaitu: 
Vol.5 / No.1: 36-71, Januari 2019,

ISSN : 2599-3348 (online)

ISSN : 2460-0083 (cetak)

a. Limbah Padat, adalah limbah yang berwujud padat. Limbah padat bersifat kering, tidak dapat berpindah kecuali ada yang memindahkannya. Misalnya, sisa makanan, sayuran, potongan kayu, sobekan kertas, sampah plastik dan logam.

b. Limbah Cair, adalah limbah yang berwujud cair. Limbah cair. Limbah cair terlarut dalam air, selalu berpindah dan tidak pernah diam. Contoh limbah cair adalah iar bekas mencuci pakaian, air bekas pembuatan industri pangan, dan sebagianya.

c. Limbah Gas, adalah limbah zat (zat buangan) yang berwujud gas. Limbah gas dapat dilihat dalam bentuk asap, limbah gas selalu bergerak sehingga penyebarannya sangat luas. Contoh limbah gas adalah gas pembuangan kendaraan bermotor, pembuatan bahan bakar minyak juga menghasilkan gas buangan yang berbahaya bagi lingkungan (Tuhu Agung R., Hanri Sutan Winata, 2016: 02).

\section{Karakteristik Limbah Cair}

Secara umum karakteristik air buangan dapat digolongkan atas sifat fisika, kimia dan biologi. Akan tetapi, air buangan industri biasanya hanya terdiri dari karakteristik kimia dan fisika. Parameter yag digunakan untuk menunjukkan karakter air buangan industri pangan adalah:

a. Parameter fisika, seperti kekeruhan, suhu, zat padat, bau,dan lain-lain.

b. Parameter Kimia, Parameter kimia dibedakan atas:

1) Kimia Organik: kandungan organik (BOD, COD, TOC), oksigen terlarut (DO), minyak/lemak, Nitrogen-Total (N-Total), dan lain-lain;

2) Kimia Anorganik: $\mathrm{pH}, \mathrm{Ca}, \mathrm{Pb}, \mathrm{Fe}, \mathrm{Cu}, \mathrm{Na}$, sulfur, $\mathrm{H}_{2} \mathrm{~S}$, dan lain-lain.

c. Beberapa karakteristik limbah cair industri tahu yang penting antara lain:

1) Padatan Tersuspensi, yaitu bahan-bahan yang melayang dan tidak larut dalam air. Padatan tersuspensi sangat berhubungan erat dengan tingkat kekeruhan air, semakin tinggi kandungan bahan tersuspensi tersebut, maka air akan semakin keruh;

2) Biochemical Oxygen Demand (BOD), merupakan parameter untuk menilai jumlah zat organik yang terlarut serta menunjukkan jumlah oksigen yang diperlukan oleh aktivitas mikroba dalam menguraikan zat organik secara biologis di dalam limbah cair. Limbah cair industri tahu mengandung bahan-bahan organik terlarut yang tinggi;

3) Chemical Oxygen Demand (COD) atau kebutuhan oksigen kimiawi merupakan jumlah oksigen yang dibutuhkan oleh oksidator (misal kalium dikhormat) untuk mengoksidasi seluruh material baik organik maupun anorganik yang terdapat dalam air. Jika kandungan senyawa organik dan anorganik cukup besar, maka oksigen terlarut di dalam air dapat mencapai nol sehingga tumbuhan, air, ikan-ikan dan hewan air lainnya yang membutuhkan oksigen tidak memungkinkan hidup; 
4) Nitrogen-Total (N-Total) yaitu fraksi bahan-bahan organaik campuran senyawa kompleks antara lain asam-asam amino, dan protein (polimer asam amino). Dalam analisis limbah cair, N-Total terdiri dari campuran N-organik, N-amonia, nitrat dan nitrit.

5) Derajat Keasaman $(\mathrm{pH})$. Air limbah industri tahu sifatnya cenderung asam, pada keadaan asam ini akan terlepas zat-zat yang mudah menguap. Hal ini mengakibatkan limbah cair industri tahu mengeluarkan bau busuk.

\section{Lingkungan Hidup}

Menurut Undang-Undang Rl Nomor 4 Tahun 1982 tentang KetentuanKetentuan Pokok Pengelolaan Lingkungan Hidup, Undang-Undang Nomor 10 Tahun 1992 tentang Perkembangan Kependudukan dan Pembangunan Keluarga Sejahtera, Undang-Undang Nomor 23 Tahun 1997 tentang pengelolaan lingkungan hidup, menyatakan bahwa lingkungan hidup merupakan kesatuan ruang dengan semua benda, daya, keadaan, dan makhluk hidup, termasuk manusia dan perilakunya yang mempengaruhi kelangsungan perikehidupan dan kesejahteraan manusia serta makhluk hidup lainnya.

Pencemaran lingkungan salah satunya terjadi akibat aktivitas manusia dan juga industry yang kurang memperhatikan lingkungan hidupnya sehingga dalam pemeliharaan lingkungan hidup perlu menetapkan baku mutu. Menurut Pasal 1 butir (13) Undang-Undang Nomor 32 Tahun 2009 tentang Perlindungan dan Pengelolaan Lingkungan Hidup, menyatakan: "Baku mutu lingkungan hidup adalah ukuran batas atau kadar makhluk hidup, zat, energi, atau komponen yang ada atau harus ada dan/atau unsur pencemar yang ditenggang keberadaannya dalam suatu sumber daya tertentu sebagai unsur lingkungan hidup".

\section{METODOLOGI PENELITIAN}

\section{Jenis Penelitian}

Penelitian ini tergolong dalam penelitian diskriptif dengan jenis data kuantitatif dan kualitatif. Untuk data kualitatif diperoleh dari hasil survey, wawancara, kaji tindak pembuatan nata de soya, kecap, dan bakteri acetobacter xylinum, data dari Dinas Perindustrian dan Perdagangan (Disperindag), Dinas Koperasi Usaha Mikro (UM) Kabupaten Banyuwangi. Sedangkan untuk data kuantitatif diperoleh dari analisis kelayakan produksi produk daur ulang dari sektor potensi limbah industri tahu dan teknologi pengolahan limbah industri tahu sebagai pengembangan UKM di Kecamatan Gambiran Kabupaten Banyuwangi, Badan Pusat Statistik Kabupaten Banyuwangi, uji beda yang dioleh dengan software spss dari analisis biaya produksi.

\section{Waktu dan Tempat Penelitian}

Penelitian ini dilakukan di Kecamatan Gambiran yang menurut hasil observasi merupakan kecamatan yang layak diperhatikan terutama masalah limbah industri tahu terutama limbah cairnya yang bisa dimanfaatkan untuk 
Vol.5 / No.1: 36-71, Januari 2019,

ISSN : 2599-3348 (online)

ISSN : 2460-0083 (cetak)

pembuatan berbagai produk makanan seperti nata de soya dan limbah padatnya untuk produk kecap, sebagai upaya pengembangan Usaha Kecil Menengah di Kecamatan Gambiran. Kecamatan Gambiran mempunyai enam desa, yaitu Desa Gambiran, Desa Jajag, Desa Purwodadi, Desa Wringinagung, Desa Wringinrejo, dan Desa Yosomulyo.

Penelitian ini dilakukan pada tanggal 30 Mei sampai dengan 30 Agustus Tahun 2018. Dengan rincian waktu sebagai berikut:

\section{Sumber Data Penelitian}

Sumber data dalam penelitian ini adalah sumber data kuantitatif eksperimen, yang diperoleh dari pembuatan nata de soya, kecap, dan bakteri acetobacter xylinum dengan menggunakan bahan baku limbah industri tahu sehingga dapat mengetahui besaran produksi yaitu antara jumlah total biaya produksi dengan jumlah total penjualan yang dihasilkan dari pembuatan nata dan kecap sehingga sehingga biaya produksi dan nilai jual sesuai yang diharapkan atau tidak, dan sumber data yang mampu disuguhkan dalam bentuk angka-angka. Sumber data yang demikian akan sangat menguntungkan di dalam pekerjaan analisis, karena secara langsung dapat diterapkan metode analisis di samping lebih bersifat objektif. Analisis kelayakan produksi dapat dijadikan keputusan masyarakat Kecamatan Gambiran untuk mengambil tindakan mengolah limbah tahu menjadi nata atau kecap, sehingga limbah cair tahu dapat dijadikan alternatif untuk pendirian produksi baru dan dapat memajukan UKM yang ada di Kabupaten Banyuwangi.

\section{Metode Pengumpulan Data}

a. Observasi, yaitu mengamati kegiatan dan ikut terjun secara langsung di Kecamatan Gambiran mulai dari perbuatan starter, produk nata dan kecap dan mengukur variabel-variabel penelitian.

b. Analisis Dokumen, dokumen dari Badan Pusat Statistik Kabupaten Banyuwangi, Kecamatan Gambiran, Dinas Perindustrian dan Perdagangan (Disperindag) Kabupaten Banyuwangi, Dinas Usaha Mikro (UM), hasil besaran produksi yang dihasilkan dari pengolahan limbah cair industri tahu menjadi produk nata dan kecap dan teknologi yang digunakannya, jumlah dan potensi industri tahu dan limbah cair yang dihasilkannya di wilayah Kecamatan Gambiran Kabupaten Banyuwangi, serta dokumen yang diperoleh dari Badan Pusat Statistik Kecamatan Gambiran, dan Badan Pusat Statistik Kabupaten Banyuwangi.

c. Eksperimen, yaitu kaji tindak pembuatan nata de soya, bakteri acetobacter xylinum, dan kecap selama kurang lebih satu bulan yang berbahan baku limbah cair industri tahu, dan limbah padat industri tahu.

d. Survey, yaitu survey langsung ke lapangan untuk menghasilkan informasi yang berkaitan dengan penelitian dan selanjutnya untuk menindaklanjuti kegiatan pengolahan limbah industri tahu sebagai pengembangan UKM 
yang ada di Kecamatan Gambiran serta mengkaji permasalahan, potensi, dan juga solusi yang ditawarkan oleh peneliti.

e. Dokumentasi, yaitu dilakukan untuk mengabadikan kegiatan di lapangan yang tidak tercantum dalam data primer sehingga hasil penelitian bisa lebih dimengerti oleh pembaca, seperti kegiatan eksperimen pembuatan nata de soya, kecap, dan pembuatan bakteri acetobacter xylinum.

f. Wawancara yaitu proses untuk memperoleh keterangan dari masyarakat Kecamatan Gambiran, terutama mereka yang mempunyai industri tahu dan masyarakat yang terkena dampak dan limbah dari industri tahu, dan dinasdinas yang terkait dengan penelitian yaitu Dinas Perindustrian dan Perdagangan (Disperindag) dan Dinas Usaha Mikro (UM).

\section{Metode Analisis Data}

\section{Gambar 2. Analisis Kelayakan Produksi Pembuatan Nata de Soya dan}

\section{Kecap}

a. Total Capital Investment (TCI)

TCI $=\mathrm{FCI}+\mathrm{WCI}$

$\mathrm{TCI}=$ Modal awal produksi $(\mathrm{Rp})$

FCI = Biaya Langsung dan Tidak langsung (Rp)

WCI = Biaya Laju Produksi/Tahun (Rp)

b. Total Biaya Produksi (TC)

$\mathrm{TC}=\mathrm{TFC}+\mathrm{TVC}$

$\mathrm{TC}=$ Biaya Total

TFC = Biaya Total Tetap

TVC = Biaya Total Variabel

c. Analisis Penerimaan (TR)

$\mathrm{TR}=\mathrm{P} \times \mathrm{Q}$

$\mathrm{TR}=$ Total Revenue

$\mathrm{P} \quad=$ Harga produk (Rp/Kemasan)

$\mathrm{Q}=$ Jumlah Produksi

d. Analisis Keuntungan $(\pi)$

$\pi=$ TR - TC

$\pi=$ Keuntungan Kotor Perusahaan

$\mathrm{TR}=$ Penerimaan Total 
Vol.5 / No.1: 36-71, Januari 2019,

ISSN : 2599-3348 (online)

ISSN : 2460-0083 (cetak)

$\mathrm{TC}=$ Biaya Total

e. Analisis Kelayakan Usaha (BEP)

$\mathrm{BEP}=\frac{T F C}{1-\frac{T V C}{T R}}($ Sulik Sutiyani, dkk., 83).

\section{HASIL DAN PEMBAHASAN}

\section{Teknologi Pemanfaatan Limbah Cair Industri Tahu Menjadi Nata de Soya}

Teknologi pemanfaatan limbah cair industri tahu sebagai nata de soya merupakan inovasi baru dari limbah yang biasnya dibuang di sungai akan dimanfaatkan menjadi produk makanan yang bernilai dan bisa dijadikan pengganti nata de coco dalam pembuatan es. Teknologi yang digunakan dalam membuat nata de soya adalah bioteknologi dari bakteri acetobacter xylinum yang telah difermentasi dengan gula, cuka, dan micin. Adapun perlakuan yang dilakukan untuk membuat nata de soya yaitu 2 kali percobaan, satu kali percobaan dengan menggunakan bahan limbah cair industri tahu, Za (food grade), gula pasir, cuka, dan acetobacter xylinum sebanyak $50 \mathrm{ml}, 100 \mathrm{ml}$ dan $150 \mathrm{ml}$. Sedangkan untuk percobaan kedua bahan yang digunakan adalah limbah cair industri tahu, cuka, vetsin/MSG, gula pasir, dan acetobacter xylinum sebanyak 50 $\mathrm{ml}, 100 \mathrm{ml}$, dan $150 \mathrm{ml}$ di masing-masing nampan yang berisi 1 liter limbah cair industri tahu. Tiga perlakuan perlakuan tersebut terletak pada banyaknya acetobacter xylinum yang ditaruh pada masing-masing nampan.

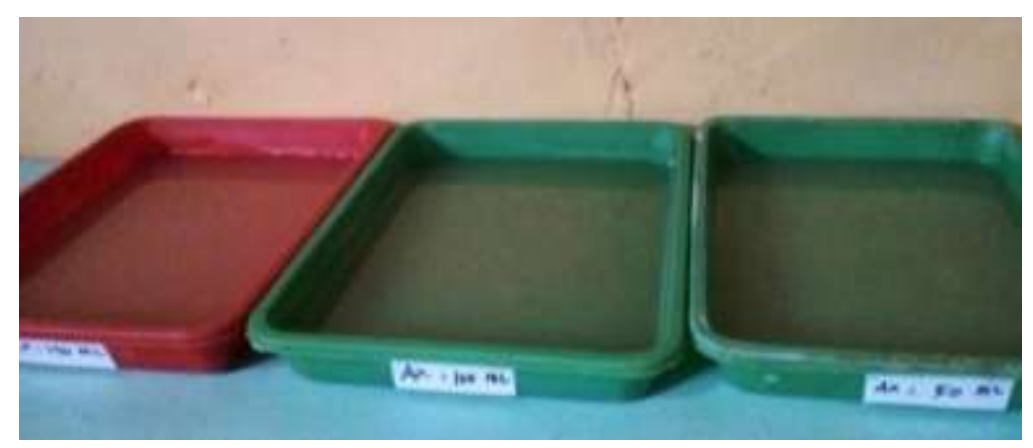

\section{Gambar 3. Pembuatan Nata de Soya dengan Menggunakan Limbah Cair Industri Tahu}

Setelah larutan pembuatan nata de soya dingin, nampan ditutup dengan koran dan diikat dengan karet, hingga tidak ada udara yang masuk dan larutan tetap steril sampai fermentasi selesai. 
Vol.5 / No.1: 36-71, Januari 2019,

ISSN : 2599-3348 (online)

ISSN : 2460-0083 (cetak)

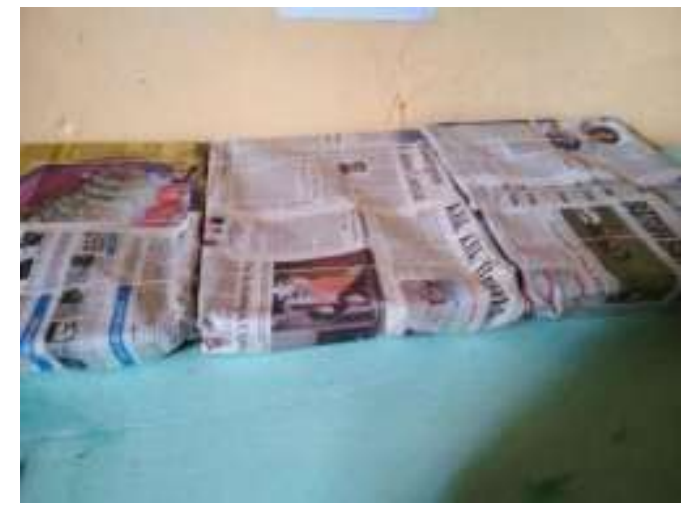

Gambar 4. Percobaan Pembuatan Nata de Soya dengan Tiga

\section{Perlakuan}

Percobaan pembuatan nata de soya yang sudah ditutup koran dan dikasih karet gelang. Koran yang digunakan penutup pembuatan nata harus steril, salah satu cara untuk menyeterilkan koran yaitu dengan menyetrikanya terlebih dahulu sebelum koran digunakan, supaya bakteri tidak masuk ke dalam larutan limbah cair tahu untuk pembuatan nata.

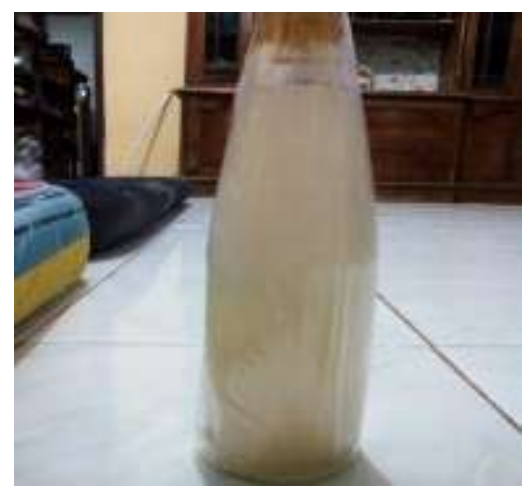

\section{Gambar 5. Bakteri Acetobacter Xylinum}

Bakteri acetobacter xylinum adalah bakteri yang digunakan untuk membuat nata de soya dengan menambahkan beberapa bahan. Bakteri ini sifatnya cair yang diperoleh dari toko biotechnologi yang berisi 600 (ml) dengan harga Rp. 40.000,-. Bakteri ini bisa digunakan untuk membuat nata de soya dengan menggunakan limbah cair industri tahu sebanyak \pm 10 liter.

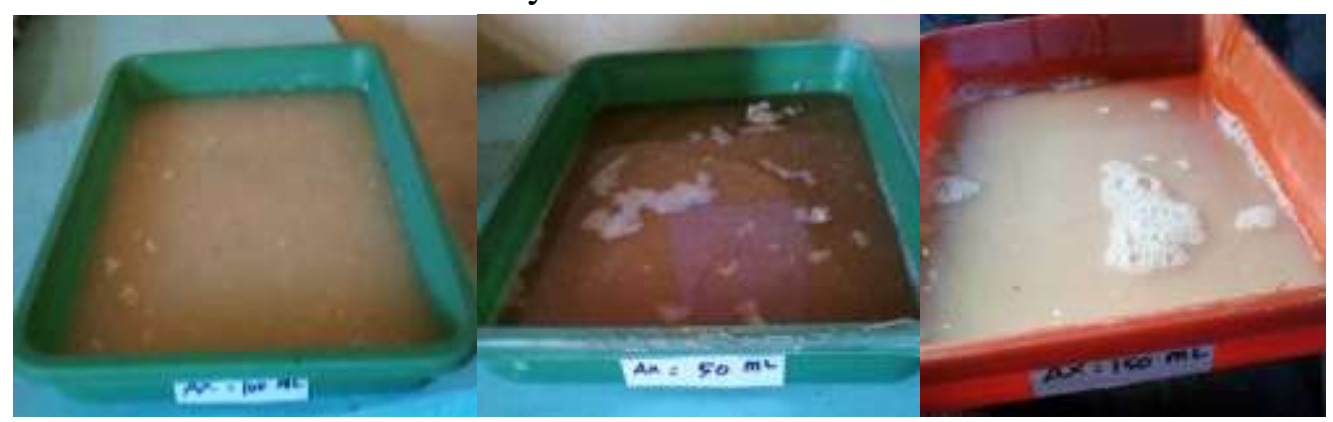

Gambar 6. Hasil Fermentasi Nata de Soya dengan Tiga Perlakuan 
Setelah melakukan eksperimen selama dua minggu pembuatan nata de soya dengan memanfaatkan bakteri acetobacter xylinum. Untuk perlakuan pertama, acetobacter xylinum yang digunakan $150 \mathrm{ml}$ untuk 1 liter limbah cair tahu, sedangkan untuk perlakuan kedua, acetobacter xylinum yang digunakan adalah $100 \mathrm{ml}$ untuk 1 liter limbah bair tahu. Untuk perlakuan ketiga, bakteri acetobacter xylinum yang digunakan sebanyak $150 \mathrm{ml}$ pada 1 liter limbah cair tahu. Hasil eksperimen menunjukkan perlakuan pertama dan ketiga mengalami kegagalan atau nata tidak jadi dan larutan berbau asam, sedangakan untuk perlakuan yang kedua dengan acetobacter xylinum sebanyak $100 \mathrm{ml}$ dalam 1 liter limbah tahu menunjukkan keberhasilan dengan terbentuknya lapisan nata yang tipis dan berwarna putih tulang transparan.

Nata yang sudah jadi tidak boleh langsung dimakan, melainkan direndam dulu selama 3 hari untuk menghilangkan zat-zat yang tidak diperlukan, setelah tiga hari nata di potong dadu tipis dan direbus dengan menggunakan gula dan essence, dan nata de soya siap dihidangkan.

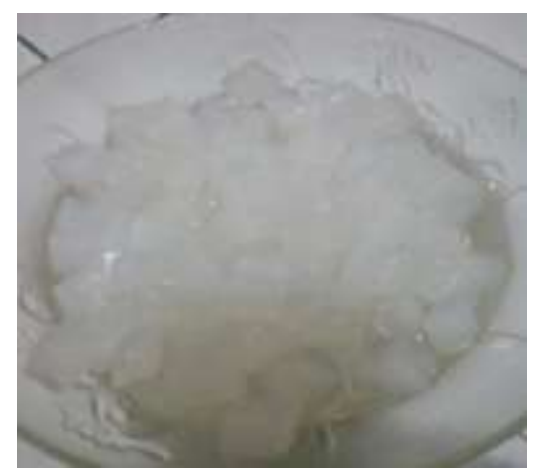

\section{Gambar 7. Nata de Soya yang Sudah Jadi}

\section{Teknologi Pemanfaatan Limbah Cair Industri Tahu Menjadi Kecap}

Teknologi pemanfaatan limbah industri tahu menjadi kecap merupakan salah satu strategi untuk mengurangi pencemaran lingkungan. Ekperimen pembuatan kecap dilakukan tiga perlakuan. Untuk eksperimen pertama dan kedua menggunakan limbah cair industri tahu dengan fermentasi oleh bakteri methanogen dari perendaman limbah dengan menggunakan garam selama 4 minggu, sedangkan untuk perlakuan ketiga pembuatan kecap dengan menggunakan limbah padat dan di fermentasi dengan rendaman air garam setelah limbah tahu dikeringkan sampai kadar air mencapai $12 \%$. Untuk perlakuan pertama dan kedua mengalami kegagalan, karena bahan utama berbau busuk, sedangkan untuk eksperimen yang ketiga yaitu berbahan dari limbah padat industri tahu, kecap mentah jadi, dan dimasak dengan bahan-bahan yang sudah disediakan dengan rasa yang tidak jauh berbeda dengan kecap yang dari kedelai asli. 
Vol.5 / No.1: 36-71, Januari 2019,

ISSN : 2599-3348 (online)

ISSN : 2460-0083 (cetak)

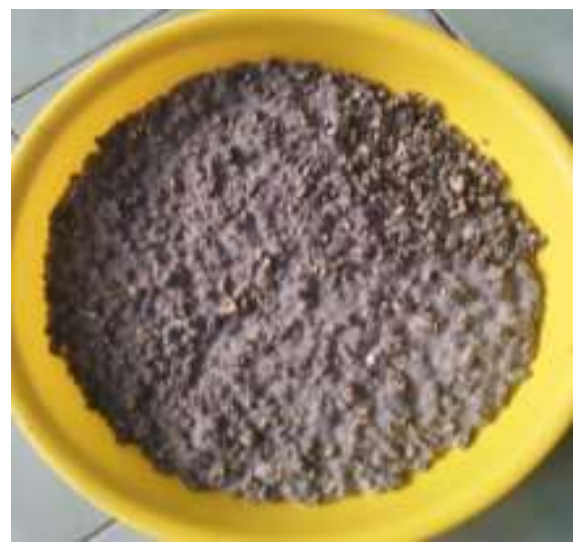

\section{Gambar 8. Pembuatan Kecap dengan Fermentasi Limbah Padat} Produksi Tahu

Pembutan kecap dari limbah padat industri tahu dengan cara fermentasi limbah padat industri tahu selama 4 hari sehingga menjadi gembos, gembos dipotong dadu $0,5 \times 0,5 \mathrm{~cm}$ dan di jemur di bawah matahari atau dikeringkan hingga kadar air tinggal $12 \%$, setelah itu fermentasi kedua dilakukan dengan cara merendam garam dan gembos yang sudah kering tadi dimasukkan kedalam larutan garam dan dibiarkan selama 5 minggu, ketika siang hari waktu cuaca tidak hujan, fermentasi ini ditaruh di luar dengan tujuan memberi udara pada larutan yang akan menjadi kecap mentah. Setelah 5 minggu, larutan disaring dan ampasnya dibuang dan air direbus. Air kecap mentah yang direbus diberi bumbubumbu yang dan direbus sampai mendidih, setelah mendidih, kecap yang sudah matang disaring kembali untuk menyaring bahan-bahan yang telah dimasukkan. Kecap yang sudah disaring siap digunakan dan dijual.

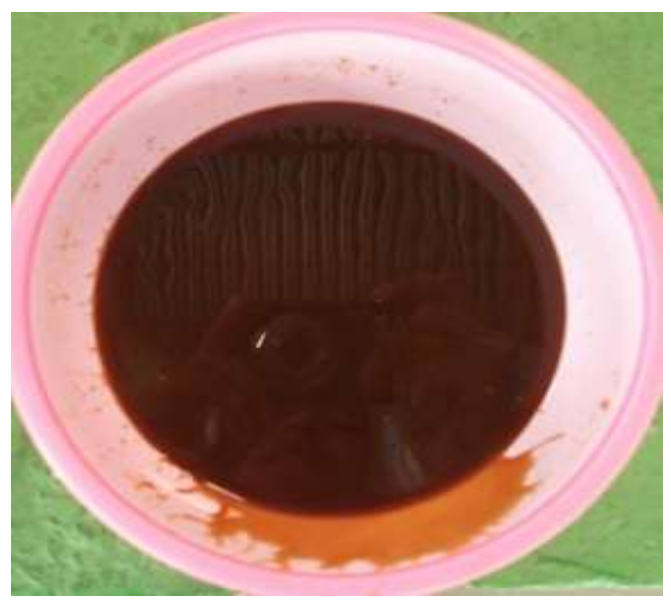

Gambar 9. Kecap yang Sudah Jadi Berbahan Baku Limbah Padat Tahu

Kecap mentah yang sudah difermentasi selam 5 minggu disaring dan diperas dengan kain tipis lalu dimasak dengan bumbu-bumbu yang telah disiapkan. Kecap berbahan limbah padat tahu berwarna hitam agak kemerahan. 
Vol.5 / No.1: 36-71, Januari 2019,

ISSN : 2599-3348 (online)

ISSN : 2460-0083 (cetak)

\section{Analisis Biaya Produksi dalam Pembuatan Nata de Soya dan Kecap}

\section{a. Biaya Produksi Nata de Soya}

Biaya produksi adalah keseluruhan biaya produksi ekonomi yang dibutuhkan dalam kegiatan produksi suatu barang. Untuk menghitung biaya produksi, harus mengetahui harga-harga barang untuk pembuatan produk nata de soya dengan biaya tidak tetap (TVC) sebesar Rp. 5,000. Bahan-bahan yang diperlukan untuk pembuatan nata de soya yaitu:

Tabel 1. Biaya Produksi Kaji tindak Pembuatan Nata de Soya

\begin{tabular}{|l|l|l|}
\hline No & Nama Bahan Pembuat Nata / 3 Liter & \multicolumn{1}{|c|}{ Harga } \\
\hline 1 & Limbah cair tahu & Rp. 0 \\
\hline 2 & Acetobacter xylinum / Starter nata & Rp. 10,000 \\
\hline 3 & Cuka & Rp. 2,000 \\
\hline 4 & MSG / Vetsin & RP. 2,000 \\
\hline 5 & Gula pasir & Rp. 2,000 \\
\hline 6 & ZA (food grade) & Rp. 500 \\
\hline \multicolumn{2}{|c|}{ Total } & Rp. 16,500 \\
\hline
\end{tabular}

Sumber: Eksperimen Kaji Tindak Peneliti

Dalam menganalisis biaya produksi untuk pembuatan nata de soya adalah sebagai berikut:

Total Capital Investment (TCI)

$\mathrm{TCI}=\mathrm{FCI}+\mathrm{WCI}$

TCI = Modal awal produksi $(\mathrm{Rp})$

FCI = Biaya Langsung dan Tidak langsung $(\mathrm{Rp})$

WCI = Biaya Laju Produksi/Tahun (Rp)

TCI pembuatan nata de soya yang memanfaatkan limbah cair industri tahu = Rp. 16,500, yaitu TCI = Rp. 16,500 + $0=$ Rp. 16,500

Total Biaya Produksi (TC)

$\mathrm{TC}=\mathrm{TFC}+\mathrm{TVC}$

$\mathrm{TC}=$ Biaya Total

TFC = Biaya Total Tetap

TVC = Biaya Total Variabel

Total biaya (TC) dalam pembuatan nata de soya adalah $\mathrm{TC}=0+\mathrm{Rp} \cdot 16,500=$ Rp. 16,500.

Analisis Penerimaan (TR)

$\mathrm{TR}=\mathrm{P} \times \mathrm{Q}$

$\mathrm{TR}=$ Total Revenue

$\mathrm{P} \quad=$ Harga produk $(\mathrm{Rp} /$ Kemasan$)$

$\mathrm{Q}=$ Jumlah Produksi

Kalau harga nata de coco harga di pasaran adalah Rp. 10,000/ 500 gram, sedangkan dalam pembuatan nata de soya dengan bahan baku limbah cair industri tahu sebanyak 3 liter akan menghasilkan nata de coco sebanyak 1600 
gram nata. Ketika nata de coco dihargai Rp. 10,000/ 500 gram karena kualitasnya A, maka nata de soya dihargai Rp. 8,000/500 gram. Jadi TR = P x Q. TR $=$ Rp. 8,000 x 1600 gram $=$ Rp. 25,500. Jadi untuk pembuatan nata de soya sebanyak 3 liter dengan jumlah produksi menghasilkan 1600 gram nata dengan menghabiskan biaya (TC) sebesar Rp. 16,500, ketika dijual akan menghasilkan uang sebanyak Rp. 25,500.

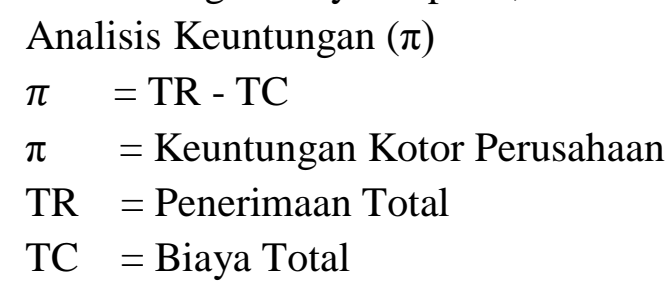

Keuntungan merupakan selisih antara total pendapatan dengan total biaya (TC). TR atau total pendapatan yang sudah dihitung diatas adalah sebesar Rp. 25,500, sedangkan untuk total biaya (TC) adalah keseluruhan biaya yang dikeluarkan selama masa produksi, jadi $\pi=\mathrm{Rp} .25,500-\mathrm{Rp}$. $16,500=$ Rp. 9,000.

Analisis Kelayakan Usaha (BEP)

$\mathrm{BEP}=\frac{T F C}{1-\frac{T V C}{T R}}($ Sulik Sutiyani, dkk., 83).

BEP digunakan untuk mengetahui di posisi mana ketika memproduksi nata de soya tidak mengalami kerugian dan juga tidak mengalami keuntungan. Kerugian diperoleh ketika total pendapatan lebih kecil daripada total biaya. Begitupun sebaliknya, ketika total biaya lebih kecil daripada total pendapatan akan mengalami keuntungan, BEP terjadi ketika :

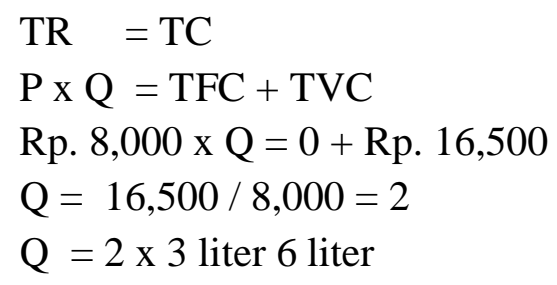

Untuk Break Event poin (BEP) dalam penelitian ini adalah 2 × $3=6$ liter. Dalam artian ketika meproduksi 6 liter limbah cair industri tahu, ketika ingin mendapatkan keuntungan yang lebih, produksi lebih banyak akan menambah profit juga bagi masyarakat sekitarnya.

Tabel 2. Analisis Biaya Produksi Pembuatan Nata de Soya

\begin{tabular}{|l|l|c|}
\hline No & \multicolumn{1}{|c|}{ Jenis Biaya Produksi } & Price (P) \\
\hline 1 & TCI / total modal investasi & 16,500 \\
\hline 2 & TC / total biaya & 16,500 \\
\hline 3 & TR / total pendapatan & 25,500 \\
\hline 4 & П / total keuntungan & 9,000 \\
\hline 5 & BEP / break event point & 6 liter \\
\hline
\end{tabular}


Vol.5 / No.1: 36-71, Januari 2019,

ISSN : 2599-3348 (online)

ISSN : 2460-0083 (cetak)

\section{b. Biaya Produksi Kecap}

Tabel 3. Bahan Pembuat Kecap dan Biaya Produksinya

\begin{tabular}{|c|c|c|}
\hline No & Bahan Pembuat Kecap / 1 Liter & Harga (P) \\
\hline 1 & Tempe Gembos & Rp. 3,000 \\
\hline 2 & Garam & Rp. 5,000 \\
\hline 3 & Daun Jeruk dan Salam & Rp. 1,000 \\
\hline 4 & Serai & Rp. 1,000 \\
\hline 5 & Pekak & Rp. 1,000 \\
\hline 6 & Kemiri & Rp. 3,000 \\
\hline 7 & Bawang Putih & Rp. 3,000 \\
\hline 8 & Lengkuas & Rp. 1,000 \\
\hline 9 & Gula Kelapa & Rp. 10,000 \\
\hline 10 & Wijen & Rp. 5,000 \\
\hline & Total & Rp. 33,000 \\
\hline
\end{tabular}

Sumber: Eksperimen Kaji Tindak Peneliti

Dalam menganalisis biaya produksi untuk pembuatan nata de soya adalah sebagai berikut:

a. Total Capital Investment (TCI)

$\mathrm{TCI}=\mathrm{FCI}+\mathrm{WCI}$

TCI = Modal awal produksi $(\mathrm{Rp})$

FCI = Biaya Langsung dan Tidak langsung (Rp)

WCI = Biaya Laju Produksi/Tahun $(\mathrm{Rp})$

TCI pembuatan kecap yang memanfaatkan limbah cair industri tahu $=$ Rp. 33, 000, yaitu TCI = Rp. 33,000 + 0 = Rp. 33,000

b. Total Biaya Produksi (TC)

$\mathrm{TC}=\mathrm{TFC}+\mathrm{TVC}$

$\mathrm{TC}=$ Biaya Total

TFC = Biaya Total Tetap

TVC = Biaya Total Variabel

Total biaya (TC) dalam pembuatan kecap adalah $\mathrm{TC}=0+\mathrm{Rp}$. $33,000=$ Rp. 33,000.

c. Analisis Penerimaan (TR)

$\mathrm{TR}=\mathrm{P} \times \mathrm{Q}$

$\mathrm{TR}=$ Total Revenue

$\mathrm{P} \quad=$ Harga produk $(\mathrm{Rp} /$ Kemasan$)$

$\mathrm{Q} \quad=$ Jumlah Produksi

Kalau harga kecap di pasaran adalah Rp. 18,000/ 800 ml, sedangkan dalam pembuatan kecap dengan bahan baku limbah padat industri tahu yang diolah dengan beberapa tahap dan fermentasi, menghasilkan kecap mateng sebanyak sebanyak 5 liter. Ketika kecap manis dihargai Rp. 18,000/ 800 gram karena kualitasnya A, maka 
kecap yang berbahan dasar limbah padat tahu dibandrol dengan harga Rp. 15,000/ 1 liter. Jadi TR = P x Q. TR = Rp. 15,000 x 5 liter = Rp. 75,500. Jadi untuk pembuatan kecap sebanyak 5 liter dengan menggunakan limbah padat industri tahu, dengan menghabiskan biaya (TC) sebesar Rp. 33,000, ketika dijual akan menghasilkan uang sebanyak Rp. 75,500.

d. Analisis Keuntungan $(\pi)$

$\pi \quad=\mathrm{TR}-\mathrm{TC}$

$\pi \quad=$ Keuntungan Kotor Perusahaan

$\mathrm{TR}=$ Penerimaan Total

TC = Biaya Total

Keuntungan merupakan selisih antara total pendapatan dengan total biaya (TC). TR atau total pendapatan yang sudah dihitung diatas adalah sebesar Rp. 75,000, sedangkan untuk total biaya (TC) adalah keseluruhan biaya yang dikeluarkan selama masa produksi, yaitu Rp. 33,000, jadi:

$\pi=$ Rp. $75,000-$ Rp. 33,000 = Rp. 42,000.

e. Analisis Kelayakan Usaha (BEP)

$\mathrm{BEP}=\frac{T F C}{1-\frac{T V C}{T R}}$ (Sulik Sutiyani, dkk., 83).

BEP digunakan untuk mengetahui di posisi mana ketika memproduksi kecap tidak mengalami kerugian dan juga tidak mengalami keuntungan. Kerugian diperoleh ketika total pendapatan lebih kecil daripada total biaya. Begitupun sebaliknya, ketika total biaya lebih kecil daripada total pendapatan akan mengalami keuntungan, BEP terjadi ketika :

$\mathrm{TR}=\mathrm{TC}$

$\mathrm{P} \times \mathrm{Q}=\mathrm{TFC}+\mathrm{TVC}$

Rp. $15,000 \times \mathrm{Q}=0+$ Rp. 33,000

$\mathrm{Q}=33,000 / 15,000=2,2$ liter kecap mateng

$\mathrm{Q}=2,2 \times$ Rp. $15,000=33,000$

Untuk Break Event poin (BEP) dalam penelitian ini adalah 2,2 liter kecap mateng. Dalam artian ketika kecap dan menghasilkan 2,2 liter kecap mateng maka akanmengalami BEP, yaitu kejadian yang mana tidak ada keuntungan dan juga tidak ada kerugian, atau disebut dengan TR $=$ TC, ketika TR > TC suatu produksi mengalami keuntungan, dan jika kejadian itu TR < TC maka suatu produksi mengalami kerugian.

Tabel 4. Analisis Biaya Produksi Pembuatan Kecap

\begin{tabular}{|l|l|c|}
\hline No & \multicolumn{1}{|c|}{ Jenis Biaya Produksi } & Price (P) \\
\hline 1 & TCI / total modal investasi & 33,000 \\
\hline 2 & TC / total biaya & 33,000 \\
\hline
\end{tabular}


Vol.5 / No.1: 36-71, Januari 2019,

ISSN : 2599-3348 (online)

ISSN : 2460-0083 (cetak)

\begin{tabular}{|l|l|c|}
\hline No & \multicolumn{1}{|c|}{ Jenis Biaya Produksi } & Price (P) \\
\hline 3 & TR / total pendapatan & 75,500 \\
\hline 4 & П / total keuntungan & 42,000 \\
\hline 5 & BEP / break event point & 2,2 liter \\
\hline
\end{tabular}

Sumber: Data Diolah

\section{KESIMPULAN}

1. Teknologi pemanfaatan limbah cair industri tahu sebagai nata de soya merupakan inovasi baru dari limbah yang biasnya dibuang di sungai akan dimanfaatkan menjadi produk makanan yang bernilai dan bisa dijadikan pengganti nata de coco dalam pembuatan es. Teknologi yang digunakan dalam membuat nata de soya adalah bioteknologi dari bakteri acetobacter xylinum yang telah difermentasi dengan gula, cuka, dan micin.

2. Teknologi pemanfaatan limbah industri tahu menjadi kecap merupakan salah satu strategi untuk mengurangi pencemaran lingkungan. Ekperimen pembuatan kecap dilakukan dengan fermentasi oleh bakteri methanogen dari perendaman limbah padat dan di fermentasi dengan rendaman air garam setelah limbah tahu dikeringkan sampai kadar air mencapai $12 \%$. Kecap mentah jadi setelah difermentasi selama lima minggu, dan dimasak dengan bahan-bahan yang sudah disediakan dengan rasa yang tidak jauh berbeda dengan kecap yang dari kedelai asli. Kecap mentah yang sudah difermentasi selam 5 minggu disaring dan diperas dengan kain tipis lalu dimasak dengan bumbu-bumbu yang telah disiapkan. Kecap berbahan limbah padat tahu berwarna hitam agak kemerahan.

3. Analisis Biaya Produksi

a. Analisis Biaya Produksi Pembuatan Nata de Soya

\begin{tabular}{|l|l|c|}
\hline No & \multicolumn{1}{|c|}{ Jenis Biaya Produksi } & Price $(\mathbf{P})$ \\
\hline 1 & TCI / total modal investasi & 16,500 \\
\hline 2 & TC / total biaya & 16,500 \\
\hline 3 & TR / total pendapatan & 25,500 \\
\hline 4 & П / total keuntungan & 9,000 \\
\hline 5 & BEP / break event point & 6 liter \\
\hline
\end{tabular}

b. Analisis Biaya Produksi Pembuatan Kecap

\begin{tabular}{|l|l|c|}
\hline No & \multicolumn{1}{|c|}{ Jenis Biaya Produksi } & Price (P) \\
\hline 1 & TCI / total modal investasi & 33,000 \\
\hline 2 & TC / total biaya & 33,000 \\
\hline 3 & TR / total pendapatan & 75,500 \\
\hline 4 & П / total keuntungan & 42,000 \\
\hline 5 & BEP / break event point & 2,2 liter \\
\hline
\end{tabular}

\section{DAFTAR PUSTAKA}


Vol.5 / No.1: 36-71, Januari 2019,

ISSN : 2599-3348 (online)

ISSN : 2460-0083 (cetak)

Abas Sato, Priyo Utomo, Hafid Susantyo Bima Adineri. (2015). Pengolahan Limbah Tahu Secara Anearobik-Aerobik Kontinue. Surabaya: Institut Teknologi Adhi Tama Surabaya. ISBN. 978-602-98569-1.0.

Anggraini, Mumu Sutisna, Yuliyanti Pratama. (2014). Pengolahan Limbah Cair Tahu secara Anaerob Menggunakan Sistem Batch. Bandung: Jurnal Institut Teknologi Bandung.

Badan Pusat Statistik Kecamatan Gambiran, Kecamatan Gambiran dalam Angka, Tahun 2014.

Badan Pusat Statistik Kecamatan Gambiran, Kecamatan Gambiran dalam Angka, Tahun 2015.

Badan Pusat Statistik Kecamatan Gambiran, Kecamatan Gambiran dalam Angka, Tahun 2016.

Badan Pusat Statistik Kecamatan Gambiran, Kecamatan Gambiran dalam Angka, Tahun 2017.

Badan Pusat Statistik Kabupaten Banyuwangi, Kabupaten Banyuwangi dalam Angka, Tahun 2018.

Firdauz, Srikandi. (2013). Polusi Air dan Udara. Yogyakarta: Penerbit Kanisius.

I ketut Arwana, Ni Gst. Ag. Gd, Eka Martiningsih, I Made Budiasa, I Gede Sukarna. (2010). Pemanfaatan Limbah Kulit Buah Kopi Arabika dalam Upaya Peningkatan Keuntungan UKM (Usaha Kecil dan Menengah) dan Pelestarian Lingkungan. Program Ipteks bagi Produk Ekspor. Fakultas Pertanian. Universitas Mahasaraswati Denpasar.

Jenie, Betty Sri Laksmi dan Rahayu, Winalti Pudji. (2014). Penanganan Limbah Industri Pangan. Yogyakarta: Penerbit Kanisius.

Kemas Ridhuan. (2016). Pengolahan Limbah Cair Tahu Sebagai Energi Alternatif

Biogas yang Ramah Lingkungan. Metro: Teknik Mesin Fakultas Tektik Universitas Muhammadiyah Metro.

Maharso, Darmiah, Zulfikar Ali As. (2014). Merubah Ancaman Bahaya Limbah Cair Industri Tahu Menjadi Peluang Ekonomi. Poltekkes Kemenkes Banjarmasin Jurusan Kesehatan Lingkungan Banjarbaru. Jurnal Kesehatan Lingkungan Vol. 11 No.

Maria Susanti Lewokeda. (2014). Pemanfaatan ampas Tahu Sebagai Bahan

Tambahan Pembuatan Kerupuk. Program Studi Teknologi Pengolahan Hasil Perkebunan, Jurusan Teknologi Pertanian Negeri Samarinda.

Muh Azhari, Sunarto, Wiryanto. (2015). Pemanfaatan Limbah Cair Tahun Menjadi Nata de Soya dengan Menggunakan Air Rebusan Kecambah Kacang Tanah dan Bakteri Acetobacter Xylinum. Surakarta: Jurnal Ekonomi dan Sains Vol. VII. No.I. Universitas Sebelas Maret Surakarta.

Nanik. (2015). Studi Pengolahan Limbah Cair Tahu dengan Menggunakan Koagulan PAC (Poli Aluminium Chloride) dan Flokulan Organoclay 
Vol.5 / No.1: 36-71, Januari 2019,

ISSN : 2599-3348 (online)

ISSN : 2460-0083 (cetak)

(Bentonit-Polydadmac). Skripsi. Program Studi Kimia Fakultas Sains dan Teknologi, Universitas Islam Negeri Yogyakarta.

Nunung Nur Hayati, Musa Hubies, dan Sapta Raharja. (2012). Kelayakan dan Strategi Pengembangan Usaha Industri Kecil Tahu di Kabupaten Kuningan Jawa Barat. Bogor: Jurnal Vol 7. No. 2 Manajemen IKM. ISSN 2085-8418.

Nurul Hikmah. (2016). Pengaruh Pemberian Limbah Tahu Terhadap Pertumbuhan dan Hasil Tanaman Kacang Hijau (Vigna Radiata L). Mahasiswa Agroteknologi Fakultas Pertanian Universitas Almuslim. Jurnal Agrotropika Hayati Vol. 3

Nusa Idaman Said, Heru Dwi Wahjono. (2013). Teknologi Pengolahan Air Limbah Tahu Tempe dengan Proses Biofilter Anaerob dan Aerob. Jakarta: Kelompok Teknologi Pengelolaan Air Bersih dan Limbah Cair Direktorat Teknologi Lingkungan, Deputi Bidang Teknologi dan Informasi, Energi, Material dan Lingkungan, Badan Pengkajian dan Penerapan Teknologi.

Nusa Idaman Said, Haryoto Indriatmoko, Nugro Raharjo, Arie Herlambang. (2013). Teknologi Pengolahan Limbah Tahu-Tempe Dengan Proses Biofilter Anaerob Dan Aerob; Kelom-pok Teknologi Pengelolaan Air Bersih dan Limbah Cair, Direktorat Teknologi Lingkungan Kedeputian Bidang Teknologi Informasi, Energi dan Material. Badan Pengkajian dan Penerapan Teknologi. 18 Desember. Jl. M.H. Thamrin No. 8, Jakarta Pusat.

Rizki Arif R. (2015). Analisis Pengelolaan Limbah Tahu di Kecamatan Adiwerna Kabupaten Tegal. Jurnal. Jurusan Ilmu Pemerintahan, Fakultas Ilmu Sosial dan Politik Universitas Diponegoro, Semarang.

Rizqie Auliana, Siti Hamidah, Fitri Rahmawati, dan Mutiara Nugraheni. (2013). Pengembangan Olahan Tahu dan Limbahnya Berbasis Teknologi Pengawetan Menuju Diversifikasi Produksi Pasca Erupsi. Yogyakarta: Jurnal Inovasi dan Aplikasi Teknologi, Vol 17. No. 2. FT. Universitas Negeri Yogyakarta.

Rizqie Auliana. (2012). Pengolahan Limbah Tahu Menjadi Berbagai Produk Makanan. Disampaikan dalam Pertemuan Dasa Wisma Dusun Ngasem Sindumartani, Kecamatan Ngemplak Sleman Yogyakarta.

Sastrawijaya, A. Tresna. (2014). Pencemaran Lingkungan. Jakarta: PT Rineka Cipta. Tuhu Agung R., Hanry Sutan Winata. (2016). Pengolahan Air Limbah Industri Tahu dengan Menggunakan Teknologi Plasma. Surabaya: Jurnal Ilmiah Teknik Lingkungan Vol. 2. No. 2. Prodi Teknik Lingkungan. Fakultas Teknik Sipil dan Perencanaan Universitas Pembangunan Nasional Veteran Jawa Timur.

Wirawan, Gatut Suliana, Taufik Iskandar. (2017). Pemanfaatan Ampas Tahu Untuk Olahan Pangan Dari Limbah Pengolahan Industri Tahu di Kelurahan Tunggulwulung Kota Malang. Malang: Jurnal Akses Pengabdian Indonesia. Vol. 1. No. 2. 64-70. 